\title{
THE ANNALS
}

AND

\section{MAGAZINE OF NATURAL HISTORY.}

[SEVENTH SERIES.]

No. 117. SEPTEMBER 1907.

XXVII.-Notes from the Gatty Marine Laboratory, St. Andrews.-No. XXVIII. By Prof. M'Lntosh, M.D., LL.D., F.R.S., \&c.

[Plates VI.-VIII.]

1. On a Porbeagle Shark with a large Suboral Aperture.

2. On the Young of the Ling.

3. On a large Example of Ommastrephes sagittatus, d'Orb.

4. On Genetyllis citrina, a new Phyllodocid.

5. On the Reproduction of Nereis diversicolor, O. F. Müller.

1. On a Porbeagle Shark with a large Suboral Aperture.

The number of porbeagle sharks caught in the gill-nets of the fishermen in St. Andrews Bay has been a subject of remark in former notes, and as time advances they do not appear to be diminishing. A female 9 feet long and in a very healthy condition entangled itself in the gill-nets for cod last November, and as the fishermen stated that it had two mouths, it was brought to the Laboratory. Inspection showed that all the internal organs were in a normal state. At a distance of 5 inches behind the tip of the mandible is a large aperture (Pl.VI. fig. 1, a), with a smoothly cicatrized margin, measuring in the preserved specimen 4 inches in transverse diameter, and blocked inferiorly by the basihyal, covered with cicatrized

Ann. \& Mag. N. Hist. Ser. 7. Vol. xx. 
skin and freely movable with the branchial apparatus. The truncated tip of the basihyal is marked by various hard wrinkles, and it projects from the ventral surface a considerable distance in profile (Pl. VI. fig. 3). When the hyoidean apparatus is pushed forward the blunt tip has a tendency to close the aperture.

Viewed internally (Pl. VI. fig. 2) the basihyal is depressed, much of it passing into the aperture in the floor of the mouth and projecting ventrally. The ceratobyals are nearly normal or only very slightly lowered. In the fresh specimen the movements of the parts were quite free, as in an ordinary example, and apparently prebension and deglutition were unimpaired.

So far as observation goes, it would seem that the fish had at one time been captured by a powerful shark-hook which had struck it from below and pierced the basihyal and the soft parts near it. In its struggles it probably wrenched the tip of the basihyal, which, with the soft parts, gave way under the powerful strain, so that about 2 inches of the basihyal with the tip of the tongue were lost and a large gap externally was caused. Whether the hook remained a short or a long time in the wound would depend on the soundness of the tackle. Though the whole hyoidean apparatus must have received a considerable wrench, yet the healing and contraction of the wound and the cicatrization of the coverings of the depressed basihyal have been so complete that comparatively little inconvenience has resulted. The large ventral aperture would take in water, whilst the plug of the basihyal would prevent the loss of food. Moreover, swallowing would not be interfered with. The slender gill-nets prove more deadly to such a powerful fish than a hook, for they yield on every side, and, though torn, soon envelop fins and tail and impede branchial respiration. On the other hand, it is comparatively rare for such a form to envelop itself with the lines, from which this shark is an adept at picking off the fishes after they are hooked.

As indicated elsewhere, the porbeagle shark has never been known to attack the human subject, yet the great muscular power and weight of an example measuring 9 feet and the Jength and sharpness of its teeth undoubtedly fit it for any predatory function. If by chance it acquired such a habit, and was as common in St. Andrews Bay in the warmer months as it is in the cold, those who swim in the inshore waters would have to face a new danger. 


\section{On the Young of the Ling (Molva molva, L.).}

J. Schmidt* , as the result of the recent unequalled international opportunities for obtaining the early stages of the food-fishes, gives an account of the pelagic postlarval stages of the ling. Yet he has only procured a single example $5 \mathrm{~mm}$. longer than that described and figured in the 'Researches' $\dagger$, and which really adds little to our knowledge, since the pigment forming the commencement of the longitudinal band characteristic of the later stage of $3 \frac{1}{2}$ inches is already indicated in the memoir cited. The $3 \frac{1}{2}$-inch stage has not been procured by the Danish author, his tigure having. been taken from the 'Researches.' He seems to be in doubt as to the passage of this longitudinally striped form into the transversely barred one found at the rocks near the pier at St. Andrews, since this coloration is diagnostic of the postlarval stages of the blue ling (Molva byrkelange, Walb.), a deep-sea form. Now only one species of ling frequents the eastern shores of Scotland, the eggs and young of which were long ago described at St. Andrews. Moreover, there is little doubt that the longitudinally striped stage of $3 \frac{1}{2}$ inches by-and-by changes into a transversely barred one with blotches along the sides. Moreover, at $13 \frac{1}{2}$ inches the coloration remains very much as at the 9 -inch stage described in the 'Researches.' The golden colour of the pectorals and the pallor of the ventrals are the same, the median division of the tip of the latter, however, being larger and broader. The barbel has additional black pigment. Perhaps the pigment-bars on the tail are less bold, though the margin is still white. In general outline the chief change, in comparison with the 9-inch stage, is the elongation of the snout in front of the eyes, the spaces between the eyes and the nostril and between the latter and the tip of the snout having. increased. This example was procured in May, and is probably about six months older than the 9-inch stage; and as the barred condition is assumed in all probability in its second year, the rate of growth given in the "British FoodFishes' $\ddagger$ may be too rapid.

Schmidt's hesitation in believing that a longitudinally striped young ling of $3 \frac{1}{2}$ inches subsequently becomes transformed into a fish with bold transverse bars is natural.

* Meddel. fra Komm. for Havunder. Serie Fiskeri, Bd. ii. no. 3 (1906).

+ Trans. R. S. Edin. vol. xxxv. p. 830, pl. xvii. fig. 4.

I M'Intosh \& Masterman, p. 283. 
There ia, however, no reason to doubt it, (1) because no smaller form with transverse bars is known at St. Andrews; (2) because all the examples (and they are many) above this size are transversely barred, the blotches remaining even to the size ( $13 \frac{1}{2}$ in.) already indicated; (3) because no other species of ling has hitherto been found in the neighbouring waters.

The above writer, in criticizing the figure of the early ling in the 'Researches' *, had forgotten to look at the text. The outline of these delicate young forms is considerably altered by strong alcohol, and whether a slip had occurred in Prof. Prince's figure or in the work of the lithographer it is now difficult to determine. At any rate, it is clearly stated in the text that "the notochord passes almost in a straight line backward to the tip of the tail, and the caudal fin is continuous with the unbroken marginal fin dorsally and ventrally. The great development of the ventral or permanent rays, however, slightly pushes the tip with the embryonic radial striations upward. The hypurals, two of which are very distinct, are developing inferiorly, and the epiurals dorsally, but they have only slightly affected the direction of the notochord. The early development of the upper caudal rays in this form is of interest, as it is in marked contrast with such forms as the Pleuronectidæ, in which the inferior fin-rays alone appear." A re-examination of the specimen in the University Museum bears out the accuracy of this description, and shows that the slightly tapered tip of the notochord projects backward nearly in the centre of the caudal rays, which are now taking the place of the embryonic fin-rays. The hypural and epiural elements are clearly visible. There is nothing in the preparation to cause any confusion with the condition in a Pleuronectid, from which the pelvic fins alone would at once distinguish the young ling.

\section{On a large Example of Ommastrephes sagittatus, d'Orb.}

Information was given by Mr. Andrew Brown, of Queen's Gardens, St. Andrews, early in January of the stranding of a large cuttlefish at the East Rocks, near the Rock and Spindle. It had, unfortunately, been much destroyed by birds before it was seen-the tentacles, funnel, all the viscera, beaks, and even a large part of the muscles of the mantle having bcen removed. A glance at the specimen showed that

* Trans. R. S. Edin. vol, xxxv. 
it was of unusual size, no similar form having been met with for forty years, when a somewhat smaller example (mantle 20 inches and tentacles 3 feet) was procured on the beach. The visits of the swarms of smaller squids which prove so troublesome to the liners are as uncertain, one having been noted in 1885 and the last in 1891 *. On the last-mentioned occasion a vast number took possession of the ground between the Bell Rock and St. Andrews, entered the latter, and even filled the salmon stake-nets, though most escaped through the meshes when the nets were hauled. Very large squids in British waters appear to be rare, one slightly larger than the present example having been described by Dr. Goodrich $†$, and two are mentioned by him as in the British Museum. Foreign specimens of great size are well known, especially on the American coasts $\ddagger$. A gigantic one was seen in 1876 , when a Scotch herring-boat, containing amongst others the attendant at the Laboratory (A. W. Brown), leaving Howth Point, was summoned by the cries of the occupants of a diver's boat. 'They found the diver, who had been surveying: a sunken tug off St. John's Point, on the ladder, to which he had been hauled (as no signal had been made for some time), with his arms pinioned by a huge cuttlefish. The men rapidly cut the diver free and allowed the cuttlefish to escape. Their impression was that the body of the cuttlefish was about a foot in diameter and the arms about 7 or 8 feet in length $\S$.

In the present mangled example now in the University Museum the length of the mantle from the tip of the tail to the collar is 25 inches. The caudal fin is 11 inches from the apex to the centre, $11 \frac{3}{4}$ inches along the outer slopes, and fully 10 inches across the base on each side, though the latter is probably underestimated, as the central portion had been lacerated by the gulls. The total breadth of the base of the caudal is thus more than 20 inches. The tentacles are absent, but the eight arms have an average length of $13 \frac{1}{4}$ inches, and the breadth of the winged or keeled arm is fully $2 \frac{5}{8}$ inches. The pen, characterized by its great strength and stiffness, is in fragments, but when laid carefully together it measures 23 inches, though in all probability in its complete condition

* Fourth Ann. Rep. Scotch Fishery Board (1885), p. 204, and Tenth Report (1891), part iii. p. 299.

† Journ. Mar. Biol. Assoc. vol. ii. n. s. p. 314 (1893).

$\ddagger$ An interesting account of one of these is given by Prof. D'Arcy Thompson, Proc. Zool. Soc., Dec. 18, 1900, p. 992.

$\S$ Part of an arm was secured for Glasgow Museum, but Prof. Graham Kerr, who hindly made a search lately, could find no trace of it. 
it approaches 25 inches. The size of the terminal pocket, in contrast with that of a specimen with a body $15 \frac{1}{2}$ inches long, is great, viz. $17 \mathrm{~mm}$. in depth at the proximal edge, and from that to the flexible tip $20 \mathrm{~mm}$. It is marked by the usual ridges.

'The description of the arms by Dr. Goodrich would do fairly for the present specimen, the latero-ventral frill of the third right arm (Pl. VII. fig. 1) being conspicuous, and at its distal third, the widest portion, is at least an inch and a half in breadth. As mentioned by Dr. Goodrich, it is supported by thick ridges. Each arm has two rows of suckers (Pl. VII. fig. 2), which differ from those described and figured by Goodrich, but agree with those of the common Ommastrephes sagittatus, and this is confirmed by Dr. Hoyle, who kindly examined both the example and its suckers, and to whom I am indebted for much information. The largest suckers on the arms measure $15 \mathrm{~mm}$. over all, and the aperture with the teeth $10 \mathrm{~mm}$. in situ. The proximal half of the rim (as it lies on the arm) has a series of small teeth, whilst the distal half has larger recurved teeth, the whole surrounded by the mobile muscular investment. The central cushion is attached to the tough pedicle. When removed from its investment (Pl. VIJ. fig. 3) the horny rim is distinctly oblique, the edge trending from the large teeth forming a long hoof-like process which apparently gives a larger surface for its attachment. The arrangement of the teeth on the rim is more or less uniform (Pl. VII. fig. 3), viz. a median very large tooth, often more or less blunted by use, and two or three somewhat smaller teeth on each side, the points of these being very sharp. Occasionally a smaller tooth occurs between the lateral teeth of one side. The teeth spring from a thickened horny rim and are sheathed externally in a hard, glistening, pale yellow substance, which appears to perform the part of enamel. So far as could be seen, no fold supporting horny plates existed round the outer margin. As the tentacles were absent nothing can be said about their suckers, but they must have been of large size, and probably with a more or less even series of teeth, as in the smaller examples.

In a specimen which has a mantle about a foot in length, and which has a diameter at its widest part of 3 inches, the arms range from $7-7 \frac{1}{2}$ inches in spirit, the third right arm having a keel, which, however, is but slightly developed in contrast with the old example. The tentacles are 10-11 inches in length and bear larger suckers than on the arms. The length of the caudal fin along its outer edge is $4 \frac{1}{2}$ inches. 
Such forms a useful contrast with the large specimen, which seems to have successfully eluded the agencies which, as a rule, render examples of this size rare on our shores, though, perhaps, abundant in the deeper waters.

\section{On Genetyllis citrina, a new Phyllodocid.}

This form was procured on a stone-coated with corallines, a bright yellow sponge, and several ascidians-brought up by a fisherman's hook in the Minch in $\mathbf{1 8 6 5}$.

The head is rounded ovate, with two black eyes of considerable size. The four tentacles had been removed, but they probably resemble those of $\frac{\dot{H}}{x}$. lutea. The tentacular cirri are similarly arranged, viz., two shorter anteriorly and two longer posteriorly. Body about 3 inches in length, much tapered anteriorly. Posteriorly it terminates in two caudal cirri. The dorsal surface is convex, the ventral marked by two elevated ridges on each side of a slightly depressed central area. The entire animal is of a most brilliant chromeyellow-deepest on the middle third, which here and there showed blackish-brown patches on the lamellæ (cirri). It tinged the water with a yellowish mucus, and also dyed the spirit in which it was immersed of the same hue.

The dorsal region of the foot has a massive, short, bluntly conical process devoid of spine or bristles, and bearing the unequally cordate lamella (cirrus), which is marked by a series of lines and reticulations from a central rib. The imbricate lamellæ are borne more or less horizontally along: the sides of the dorsum, leaving the central region bare. The semicircular gap at the base of the lamella fits the rounded extremity of the division to which it is attached. The short setigerous region is bifid at the tip and supported by a black spine, and a group of bristles shorter than in $G$. lutea, the translucent shafts being slightly bent, and with a dilated distal end which has a few sprkes on each side. The terminal process is finely tapered and shorter than in G. lutea. The edge shows no distinct serrations, though the adherence of particles would indicate them. Attached to the ventral and posterior part of the region is an irregularly reniform ventral cirrus, vertical in position. The inferior border is rounded, but the superior is truncated, with a tendency to a point at the upper and outer angle. The cirri-both superior and interior-vary little in shape throughout the body.

The stone was coated with the yellowish sponge, but its connection with habits of the Genetyllis is unknown. The 
annelid crawled actively amongst the ascidians and other grow ths to escape capture.

This form clearly approaches Genetyllis lutea, Malmgren, but the setigerous region supported by a black spine and carrying shorter bristles with shorter terminal processes than in that species point to separation.

\section{On the Reproduction of Nereis diversicolor, O. F. Müller.}

Various statements have been made about the reproduction of this species. Thus Max Schultze * refers to the occurrence of the young in the body-cavity, having apparently considered Koch's statements in regard to Marphysa sanguinea as true.

Cuvier and Grube, again, thought Arenicola was hermaphrodite, and Rathke placed Amphitrite in the same category, though each might be more or less male or female. An interesting résumé of the views of the period is given by Frey and Leuckart $\uparrow$. A. Krohn, again, describes from Nice a viviparous Syllis (S. vivipara) allied to $S$. Armandi, only the now form has simple tips to the terminal pieces of the bristles. The enclosed young form has 23 segments and is like the adult.

In Balfour's 'Embryology' $\ddagger$ it is stated that "a few forms (e. g., Eunice sanguinea, Syllis vivipara, and Nereis diversicolor) are viviparous." Considerable reliance in more recent times has been placed on the observations of Mendthal on the supposed hemaphroditism of Nereis diversicolor. This author seems to have been attracted to the subject by the previous work of Schröder $\S$, who found embryos in the morula-stage. Mendthal described the species from the bay of Pillau as carrying both eggs and testes in June, and he was the more inclined to believe in its hermaphroditism since Schröder met with only 3 males out of 48 examples. He places and figures the testes in the dorsal region as pear- or flask-shaped masses to the exterior of the dorsal longitudinal muscles. The supposed testes, therefore, occupy the same position as the outer limb of Dr. Goodrich's dorsal organ, and it may be that the cilia were a source of misapprehension. On the other hand, he describes the ova as developing at the bases of the feet, the figure representing them in the position of the segmental organ.

* 'Entwickelung Arenicola piscatorum \&c.,' p. 214 (Halle, 1856).

† Beitr. z. Kenntniss wirb. Thiere, p. 82 (1847).

† Vol. i. p. 319.

$\S$ This author's paper has not yet been obtainable. 
De St. Joseph, however, could not corroborate the foregoing observations. Gravier, on the other hand, considers that hermophroditism and viviparity may exceptionally exist in this form, and in the 'Cambridge Natural History' it is stated that viviparity is characteristic of it.

The annelid is very common on many parts of the British shores, burrowing in clay, sand, mud, peat, and similar media, and at St. Andrews it abounds at the upper end of the harbour amidst muddy clay on the sides of the Kinness Burn which enters there. During last winter especially careful observation of the species was carried out to test the condition as regards reproduction; yet though both hermaphroditism and viviparity have been discountenanced, it has not been possible to find the worm either discharging from its tunnel in the mud its eggs and sperms or becoming pelagic at maturity and thus dispersing the sexual elements. So far as can be observed, the former, perhaps, seems to be the more likely, though no certainty exists on this head.

In the middle of October the majority of the examplesboth large and small-were females with fairly developed ova, which were almost visible to the naked eye and easily under a lens. In these the vascularity of the feet had slightly increased, but no change in the lobes of the feet or in the bristles had occurred. Amongst the ova in the cœlomic space were numerous pale granular cells, apparently modified perivisceral corpuscles. Very few males were obtained at this time, and these for the most part were undeveloped.

In November comparatively few ova were attached to the ventral plexuses, most being free in the perivisceral space. On the other hand, the vascular plexuses in the region of the ciliated organ were laden with dense groups of rather coarsely granular cells-sometimes in lobular masses, and it was considered that these pale cells were associated with the growth and maturation of the ova in the cœlomic space. The ova had considerably increased in size towards the end of the month.

In transverse section * the body of the annelid at this time differed little from the type except in the presence of ova, which appear most abundantly, in the sections, at the bases of the feet and extending into their lobes. The number in the cœlom was not large, many, in all probability, having: fallen out. The dorsal and ventral longitudinal muscles showed little change, the pennate fold of the latter being well

* I am indebted to Dr. Tosh for valued aid in making these sections and in other respects. 
developed. The oblique muscles pass at each side slightly below the nerve-cord to be attached to the basement-membrane; and at least three neural canals are present, the larger lateral having a coagulable fluid internally, and each runs along the outer border of the nerve-trunk between the pairs of ganglia. The median or dorsal canal, again, appears to have a separate strand in the interganglionic region, and when it reaches the ganglia it splits into two trunks in certain sections. The muscles of the bases of the feet and of the bristles are also strong. The wall of the alimentary canal appears to be of normal thickness.

The annelids remained very much in the same condition during December, the great majority of those examined being females, so much so that it was at first considered probable that, as authors had stated, a complex sexual condition existed ( $e_{0} g$. alternate development of the reproductive elements); but as a few males were still met with and no trace of an intermediate stage occurred, such complexity could not be proved. This month the only difference in the sections of the females was the increase in the size of the ova, the abundance of the colomic corpuscles (Pl. VIII. fig. 1), and the distention of the body-cavity and the bases of the feet, so that the muscles of the wall were stretched. The vascularity of the outer surface of the gut also appeared to be increased. The segmental organs showed no feature of note. In the males the perivisceral cavity and the bases of the feet contained dense masses of translucent granular cells, the large nuclei of which stained deeply with eosine.

The great increase of the large granularcells (Pl. VIII. fig.3) in the cœlomic cavity in January was a feature of moment, especially in those females in which the ova were small. The enormous masses of these cells distended the bodies of the females and they probably increased by division, each being filled with spherules. In glancing at the living annelids a pale, or greyish, green hue characterized the posterior region of the body in the females; whilst the anterior segments had their vascularity increased, the dorsal vessel of the foot and its branches especially were distinct. When the posterior region was punctured, the masses of ova had a pale greenish colour as in the previous months, and were similarly unfertilized. As many have discharged ova, it would appear that fertilization is external as in allied forms.

The sexes are not always distinguished by colour, both males and females being greenish or dull yellowish, though the males are often paler. No change in eyes, feet, or 
bristles is apparent. In many an opaque, dull whitish condition occurs in the anterior feet, which are filled with the large granular perivisceral corpuscles. Moreover, almost all have a touch of white at the base of the dorsal cirrus-from one end of the body to the other, a similar touch occurring at the tip of the ceratophore of each tentacular cirrus.

Mendthal * figures two examples, one of the general brownish-orange hue of the ordinary type, and the other of this colour in the anterior fourth, whilst the rest is of a grassgreen tint. He considers that the latter (green) colour is due to a diet of green algæ, a condition which is not in accordance with the observations at St. Andrews, where the greenish hue appeared to be the result of the presence of masses of more or less ripe ova. There is no reason, however, why a diet of Ulva or other green alga should not tint the digestive canal green.

In the male the sperm-cells (Pl. VIII. fig. 2) filled the various cavities even to the bases of the dorsal cirri throughout January, but though the body-wall was frequently distended, no degeneration of the muscular bands could be observed. In the females the size and abundance of the ova in particular examples varied, but, as a rule, the granular ova with a slightly stained nucleus and a more deeply stained nucleolus were more or less advanced towards maturity. Occasionally an example with few and small ova appeared. In some of these the muscular walls of the body were contracted, and very few ova, and these of small size, occurred in the perivisceral space. More frequently they were found in the feet. Masses of ovigerous tissue were attached to the vessels near the bases of the latter; and cellular masses (it may be parts of the dorsal organ) with boldly stained nuclei passed upward at the bases of the feet within, as well as without, the lateral lobe of the dorsal longitudinal muscles, and similar cells passed into all the spaces of the feet-in specimens having a considerable number of large ova. These loose cœlomic masses probably represented the cells alluded to in the living forms.

In February the increase in size and the division of the sperm-cells formed the most noteworthy feature, but no free sperms were seen. In the other sex the ova in many had considerably increased in size, and from the appearance of the annelids a large number of ova must have been discharged.

* Untersuch. u. d. Mollusken u. Anneliden des frischen Haffs, p. 9, Taf. figs. 1 \& 2 (Konigsberg, 1889). 
Signs of rapid division of the sperm-cells characterized many males in the middle of March, and towards the end of the month the perivisceral cavity formed a vast reservoir for the male elements. The body-walls were stretched, the muscular layers diminished, and the alimentary canal collapsed. The tubes of the segmental organ had also enlarged, so that sperms could readily find issue by the segmental papilla. Though the nuclei of the walls of the organ and its tubes were everywhere distinct, no trace of sperms was at any time found within it, so that they probably escape by rupture of the body-wall, as in allied forms.

The ova in the various examples throughout March appeared to attain full size and maturity, viz. about $1524 \mathrm{~mm}$., and they were probably shed by rupture of the body-wall, the vast numbers set free, even from a limited area, affording an indication of the almost illimitable resources of nature in the sea. Whether the sexes discharge their elements in situ or by a terminal pelagic stage could not be ascertained. None were captured in the tow-nets dragged, by day and by night, up stream at ebb-tide, and no indication of any change in the structure of the feet, bristles, or eyes, and no shrivelling: of the posterior region of the body as in the very interesting Ceratocephalus Osawai of Akira Izuka *, common in the estuary of the Sumida River in Tokyo, occurred. If one may hazard a conjecture, it is probable that the sperms and ova are discharged on the sites inhabited by the annelids, and the larvæ by-and-by carried seawards. There is no doubt, however, that, without change in the condition of the feet and bristles, the species is an apt swimmer, progressing through the water swiftly in graceful screw-coils.

'Towards the end of May (29th) and for some time previously signs of degeneration appeared in certain ova, as if they were in process of absorption. These ova were smaller, minutely granular, and with larger oil-globules. The larger ova had lost the germinal vesicle and spot, and transmitted light more readily than formerly. Nothing was seen to suggest the view that certain ova were undergoing development, for, when kept in vessels both of sea-water and fresh water, they were rapidly disintegrated.

Some females at this date have shed all their ova, and are of a pale brownish-yellow colour, occasionally with a minute dusting of yellow grains along the dorsum.

Having failed to secure the early larvæ by any of the methods alluded to, masses of the clayey mud with the adults

* Journ. Coll. Sc. Univ. Tokyo, vol. xvii. art. ii. (1902). 
in situ were brought from the banks of the Kinness Burn near the harbour towards the end of May, and a strict scrutiny made of the tubes and the mud lining them. Numerous postlarval forms were thus obtained, but no trace of trochophores or other early stages. Whether these stages had been passed in such an environment before the examination, or whether the later larvæ to be subsequently described had settled in the mud of the tubes after a pelagic stage is yet undetermined.

The youngest stage observed has three bristled segments (Pl. VIII. figs. $4 \& 5$ ), a head with two short palpi, and two short frontal tentacles. The eyes are imperfectly differentiated, consisting of an irregular group of black pigment-granules (fig. 5). A tentacular cirrus occurs on each side opposite the eyes. The three feet are nearly alike, each with a bristletuft and a small dorsal cirrus, or the first is rudimentary (fig. 4). A minute caudal cirrus is at each side of the posterior end. Between the last foot and the pygidium is a projection, indicating a segment. The proboscis has a pair of jaws each with three long teeth, including the anterior fang (Pl. VIII. fig. 6). The opaque part of the gut extends over the last two bristled segments. The minute bristles already present the typical structure of camerated shaft and homogomph articulation of the end of the shaft, and are in two bundles in each foot.

No younger form has yet been found amongst the mud or the adults, so that it is probable that they settle down at this stage. Moreover, no pelagic larvæ appeared in the vessels; yet as the postlarval forms with three bristled segments occurred in the mud of the tubes of the adult, it would appear that all do not wander.

When the postlarval form has four bristled segments the head has two eyes on each side, placed close together and posteriorly, a pair of short frontal tentacles, short palpi which present no distal articulation, a pair of tentacular cirri, and two short anal cirri. Behind the head, which bears the tentacular cirri, is a region with only bristles on each side; a foot with a large bristle-tuft and a minute dorsal cirrus follows, and then a second foot of similar structure. A rudimentary foot comes next, with a bristletuft on one side. A rudimentary ventral cirrus occurs on each foot. A pair of minute jaws having two teeth behind the anterior fang is found in the proboscis. Vast swarms of Infusoria (like monads) frequent the moist and odoriferous mud in which the young Nereids occur.

The postlarval form of the 28th May (Pl. VIII. fig. 7) 
has a head with two comparatively large frontal tentacles and two stumpy palpi with very short terminal segments that only occasionally are visible, two pairs of tentacular cirri, the last with a spine in the dorsal, five pairs of distinctly bristled feet, with more evident dorsal and ventral cirri and slightly brownish spines, besides two rudimentary ones behind and a large pygidium with two caudal cirri. The cirrus of the first bristled segment is elongating, but the bristles are shorter than in the succeeding foot. The mouth is a wide aperture, followed by the somewhat ovoid proboscis, which is armed with two translucent jaws having three prominent teeth which are proportionately longer than in the adult. The proboscis is narrowed posteriorly and joins a large opaque, yellowish, glandular region, broad and truncated in front and diminishing posteriorly and terminating in the pale rectal part of the gut and its dorsal anus. The opaque glandular region stretches from the space between the second and third feet to the last bristled foot, and shows the groups of oily granules so characteristic of the glands on the walls of the alimentary canal. A pair of slightly opaque ovoid glandular bodies, the segmental organs, lie behind the first complete foot, just in front of the opaque region of the gut, and active ciliary action is occasionally noticed in them.

In the postlarval form with six bristled feet the eyes are better defined and the palpi, frontal tentacles, and tentacular cirri are larger. The dorsal cirrus of the first bristled segment is the longest in the animal, but there is no spine. The spines are darker, the posterior end remains bifid, and three teeth occur behind the anterior fang in each jaw.

When seven bristled feet are present the caudal cirri are considerably longer, the last foot (seventh) having a few short bristles, a short dorsal cirrus, two short spines, and a minute rudiment of a ventral cirrus. Behind is an indication of the eighth foot as a lateral projection, with a minute papilla representing the dorsal cirrus. Internally is the tip of a minute spine, but no bristles. The ventral of the first tentacular cirrus (opposite the eyes) is a short subulate process; that of the next segment is indistinct, though, with the exception of the caudal cirri, the dorsal is the longest of the series. The bristles of this segment are always short and in contrast with the next segment, which shows the segmental organs immediately behind. Opacities in the corresponding parts of the following feet indicate the early development of these organs throughout. 'Iraces of a fourth tooth behind the great anterior fang of the maxillæ are visible. This description might also apply to a postlarval form with eight 
bristled feet (Pl. VIII. fig. 8), the latest stage observed towards the end of May.

If the young Nereids of the foregoing stages are left in the vessels beside the adults the larger examples rapidly disappear. They are probably devoured by the adults, only the minute stages escaping capture, and in all likelihood they, too, would by-and-by be found out and captured; yet, as in the fishes, these checks have little influence on the permanent abundance of the species.

On the 17 th July the young forms are found on the same sites, but considerable progress has been made in development. The head in outline nearly resembles that of the adult and is marked by whitish pigment in front of the eyes in the smaller, brownish in the older, which are definitely formed on each side, the anterior pair being somewhat larger and furnished with lenses. The frontal tentacles and the palpi are well formed and show numerous fine palpocils, the mobility of the distal segment of the palpi being noteworthy. The two pairs of tentacular cirri are now much longer, the dorsal stretching outward like fine hairs as the animal pushes its snout forward. They retain the proportions to each other of the adult, though they have not yet reached full development in any case. The ventral of each is considerably shorter than the dorsal, but projects clearly on each side, the first rather longer and thicker at the base than the frontal tentacles. The body is now elongated, having from sixteen to twenty bristled feet, and is marked along the centre by a yellowish or brownish streak, often slightly moniliform or zigzag from the intestinal contents, and a whitish dot is observed in some at the bases of the feet. The massive and somewhat ovoid proboscis has six teeth behind the great anterior fang, and the narrow part of the canal behind it is usually firmly contracted (and empty). The first part of the gut behind the post-proboscidian narrow region is the largest, and for some distance it is not marked by lateral constrictions, as in the succeeding portion. Most of the feet anteriorly present a condition approaching that of the adult, though the dorsal cirrus is shorter. Only the last two feet are devoid of bristles externally. The caudal cirri are now considerably longer. The circulation of the red blood in the dorsal and ventral trunks is now evident. The segmental organs extend backwards to the posterior feet, though not quite to the tail.

So far as observed at St. Andrews, therefore, there is no foundation for the statement that the Scotch representatives are hermaphrodite, and still less that they are viviparous, as 
mentioned by Max Schultze, by the 'Cambridge Natural History,' and by Gravier. Max Schultze * gives a circumstantial account of finding female examples in April at Greifswald with ciliated eggs and pear-shaped larvæ in the body-cavity, and he figures two of the latter, hundreds of which occurred in the cavities at the bases of the feet. His figures, however, give rise to doubt as to the nature of the ciliated forms, which have the narrow end of the pear anteriorly with the two eyes at some distance behind it. In one, indeed, the mouth is indicated behind the eyes as a small radiated disk. The posterior end of the larva is broad and rounded. In the light of the condition at St. Andrews doubt arises as to correctness of the interpretation, more especially in view of the structure of the larva; but it is right to give a margin for possible variations in regard to internal fertilization under certain circumstances. Yet it seems unlikely.

The foregoing interpretation as to the mode of reproduction would seem to be most in accordance with observation, since on the 28th May masses of clayey mud brought from the habitat of the species and with the annelids in situ showed many free ova amongst the mud coating the walls of the tube, and, further, of various postlarval examples.

\section{EXPLANATION OF THE PLATES.}

\section{Plate VI. $†$}

Fig. 1. Ventral view of the head of a porbeagle shark, 9 feet long, showing the rounded tip of the hyoidean apparatus $(a)$ projecting from its smoothly finished aperture.

Fig. 2. Aspect of the same region from the interior of the mouth.

Fig. 3. Lateral view of the preparation, indicating the projection of the hyoidean boss.

N.B.-The first figure is drawn to a larger scale than figs. 2 and 3 , which are nearly equally reduced.

\section{Plate VII.}

Fig. 1. Third right arm of the large Ommastrephes sngittatus, d'Orb., showing the keel to the left, the web with its supporting rays, and the suckers. A portion of the web has been removed. Slightly reduced.

* 'Entwickelung von Arenicola piscatorum nebst Bemerk. über Entwickel. and. Kiemenw. 1856 , p. 214, Taf. ix. fige. 11 \& 12.

$\dagger$ I am indebted to the Carnegie Trust for these figures, those of Pl. VlI., and four of Pl. VIII. 
Fig. 2. Inner face of the same arm with four suckers. Slightly enlarged. Fig. 3. Horny rim of a sucker, showing the arrangement of the sharp teeth, usually on the distal margin of the rim. Enlarged.

\section{Plate VIII.}

Fig. 1. Masses of perivisceral corpuscles near the bases of the feet of Nereis diversicolor, O. F. M., 7th December, 1906. $\times$ Zeiss oc. 2 , obj. F.

Fig. 2. Male elements. Similarly magnified.

Fig. 3. Large corpuscles floating freely in the cœlomic space, 21st January, 1907. $\times$ Zeiss oc. 2 , obj. F.

Fig. 4. Postlarval form of 28 th May, 1907, with three bristle-tufts (one rudimentary).

Fig. 5. Another of same date with three bristle-bundles.

Fig. 6. Mandible of the foregoing. $\times$ Zeiss oc. 2, obj. D.

Fig. 7. Postlarval form of 28 th May with tive bristle-bundles. Magnified. Fig. 8. Postlarval form of 28th May with eight bristle-bundles. Magnified.

\section{XXVIII.-Descriptions of apparently new Species and Sub-} species of Mammals belonging to the Families Lemuridæ, Cebidæ, Callitrichidæ, and Cercopithecidæ in the Collection of the Natural History Museum. By D. G. Elliot, D.Sc., F.R.S.E., \&c.

HAVING for some time been engaged in the study of the Primates, it was found necessary to investigate the material contained in the various great museums in the Old World, and, beginning with the vast collection of the Primates contained in the Natural History Museum, London, my friend Mr. Oldfield Thomas, Curator of Mammalogy in that institution, not only most kindly gave me every facility for pursuing my studies, but also requested that I would describe any specimen that I found in the collection that I considered might be new. In various genera the Museum is very rich both in number of species and examples, and the advantage one possessed in working with such splendid material is exemplified in the comparatively large number of new forms contained in this paper. My thanks, therefore, are especially due to Mr. Thomas for the opportunity, not only of examining the great collection under his care, but of making known to mammalogists the various forms that seemed worthy of special recognition. 


\section{$2 \mathrm{BHL}$ Biodiversity Heritage Library}

M'Intosh, William Carmichael. 1907. "XXVII.-Notes from the Gatty Marine Laboratory, St. Andrews.-No. XXVIII." The Annals and magazine of natural history; zoology, botany, and geology 20, 169-185.

https://doi.org/10.1080/00222930709487321.

View This Item Online: $\underline{\text { https://www.biodiversitylibrary.org/item/85040 }}$

DOI: https://doi.org/10.1080/00222930709487321

Permalink: https://www.biodiversitylibrary.org/partpdf/64138

\section{Holding Institution}

Smithsonian Libraries

\section{Sponsored by}

Smithsonian

\section{Copyright \& Reuse}

Copyright Status: Public domain. The BHL considers that this work is no longer under copyright protection.

This document was created from content at the Biodiversity Heritage Library, the world's largest open access digital library for biodiversity literature and archives. Visit BHL at https://www.biodiversitylibrary.org. 